21 Rose LM, Ginsberg AH, Rothstein TL, Ledbetter JA, Clark EA. Selective loss of a subset of helper cells in active multiple sclerosis. Proc Natl Acad Sci USA 1985;82:7389-93.

22 Morimoto C, Hafler DA, Weiner HL, et al. Selective loss of the suppressor-inducer $T$ cell subset in progressive the suppressor-inducer $T$ cell subset in progressive multiple sclerosis. Analysis with anti- $2 \mathrm{H}$
antibody. N Engl f Med 1987;316:67-72.

23 Emery P, Gentry PKC, MacKay IR, Muirden KD, Rowley $M$. Deficiency of the suppressor-inducer subset of $T$ lymphocytes in rheumatoid arthritis. Arthritis Rheum 1987;30:850-6.

24 Ginsberg AH, Gale MJ, Rose LM, Clark EA. T cell alterations in late postpoliomyelitis. Arch Neurol 1989;46:497-501.

25 Besinger UA, Toyka KV, Homberg M, Heininger $K$, Hohlfeld R, Fateh-Moghadam A. Myasthenia gravis: Long term correlation of binding and bungarotoxinblocking antibodies against acetylcholine receptors with blocking in lisease severity. Neurology 1983;33:1316-21.

26 Pawelec G, Bühring HJ, Busch FW, Kalthoff F, Wernet P.
Different signals for stimulation and lymphokine secretion by a $\mathrm{CD} 3^{+}$WT $31^{-}$cloned cytotoxic lymphocyte. Cell Immunol 1988;113:329-40.

27 Van de Griend RJ, Carreno M, Van Doorn R, et al. Changes in human $T$ lymphocytes after thymectomy and during senescence. F Clin Immunol 1982;2:289-95.

28 Haynes BF, Harden EA, Olanow CW, et al. Effect of thymectomy on peripheral lymphocyte subsets in myasthymectomy on peripheral lymphocyte subsets in myasthenia gravis: selective effect on T cells in patic

29 Rose LM, Ginsberg AH, Rothstein TL, Ledbetter JA, Clark EA. Fluctuations of CD4+ T cell subsets in remitting-
EA relapsing multiple sclerosis. Ann Neurol 1988;24:192-9.

30 Choffion M, Weiner HL, Morimoto C, Hafler DA. Loss of functional suppression in circulating suppressor inducer $(\mathrm{CD} 4+2 \mathrm{H} 4+) \mathrm{T}$ cells in multiple sclerosis. Ann Neurol 1988;24:185-91.

31 Reichert RA, Weissman IC, Butcher EC. Dual immunofluorescence studies of cortisone-induced thymic involution: evidence for a major cortical component to cortisone resistant thymocytes. F Immunol 1986;136:3529-34.

\section{Romberg's Sign}

Moritz Heinrich Romberg of Berlin published his classic Lehrbuch in sections between 1840-6; Sieveking translated the "Manual" into English in 1853. The description of that most misspelled of all eponyms lies in his description of tabes dorsalis.

"Early in the disease we find the sense of touch and muscular sense diminished, while the sensibility of the skin is unaltered in reference to temperature and painful impressions. The feet feel numbed in standing, walking or lying down, and the patient has the sensation as if they were covered in fur; the resistance of the ground is not felt ... The gait begins to be insecure ... he puts down his feet with greater force ... The individual keeps his eyes on his feet to prevent his movements from becoming still more unsteady. If he is ordered to close his eyes while in the erect posture, he at once commences to totter and swing from side to side; the insecurity of his gait also exhibits itself more in the dark. It is now ten years since I pointed out this pathognomonic sign, and it is a symptom which I have not observed in other paralyses, nor in uncomplicated amaurosis ... . in no case have I found it wanting."

Romberg gives a fulsome account of the muscular weakness, urinary frequency, retention and incon- tinence, and the constricting pains that

"encircle the trunk like a hoop, and not infrequently renders breathing laborious... troublesome in sleep, causing them suddenly to start up and scream. Others complain of a heavy weight pressing upon the rectum and bladder, others again of colic and gastric pains; the majority suffer from pain shooting through the legs, and a sense of pricking, itching, burning, or cold in the skin of the lower as well as the upper extremities;"

The whole clinical spectrum is described, the natural history extending over several-as many as ten to fifteen-years. The wasting (tabes) of the cord and roots is related, but "as yet we possess no microscopic investigation of the atrophied portion."

Romberg also gives a brief but unmistakeable description of the pupils to be described 16 years later by Douglas Moray Cooper Lamb Argyll Robertson. Curious how students add an undropped ' $h$ ' in one and insert a non-existent hyphen in the other.

JMS PEARCE

1 Romberg MH. A Manual of the nervous diseases of man, $\mathrm{Vol} 2$, (EH Sieveking trans) London. Sydenham Society, 1853:395-401. 